\title{
Effect of filter extraction solvents on the measurement of the oxidative potential of airborne $\mathrm{PM}_{2.5}$
}

\author{
Maria Chiara Pietrogrande ${ }^{1}$ (D) $\cdot$ Dimitri Bacco $^{2} \cdot$ Arianna Trentini $^{2} \cdot$ Mara Russo $^{1}$
}

Received: 2 July 2020 / Accepted: 18 January 2021 / Published online: 9 February 2021

(C) The Author(s) 2021

\begin{abstract}
Solvent extraction of $\mathrm{PM}_{2.5}$ samples collected on the filter is a preliminary step for assessing the $\mathrm{PM}_{2.5}$ oxidative potential (OP) using cell-free assays, as the dithiothreitol (DTT) and the ascorbic acid (AA) assays. In this study, we evaluated the effect of the solvent choice by extracting ambient $\mathrm{PM}_{2.5}$ samples with different solvents: methanol, as organic solvent, and two aqueous buffers, i.e., phosphate buffer (PB) and Gamble's solution (G), as a lung fluid surrogate solution. Both the measured volumebased $\mathrm{OP}_{\mathrm{V}}{ }^{\mathrm{DTT}}$ and $\mathrm{OP}_{\mathrm{V}}{ }^{\mathrm{AA}}$ responses varied for the different extraction methods, since methanol extraction generated the lowest values and phosphate buffer the highest. Although all the tested solvents produced intercorrelated $\mathrm{OP}_{\mathrm{V}}{ }^{\mathrm{DTT}}$ values, the phosphate buffer resulted the most useful for $\mathrm{OP}^{\mathrm{DTT}}$ assessment, as it provided the most sensible measure (nearly double values) compared with other extractions. The association of the measured $\mathrm{OP}_{\mathrm{V}}$ values with $\mathrm{PM}$ chemical composition suggested that oxidative properties of the investigated $\mathrm{PM}_{2.5}$ samples depend on both transition metals and quinones, as also supported by additional experimental measurements on standard solutions of redox-active species.
\end{abstract}

Keywords $\mathrm{PM}_{2.5} \cdot$ Oxidative potential $\cdot$ Filter extraction solvents $\cdot$ Phosphate buffer $\cdot$ Gamble's solution $\cdot$ Methanol $\cdot$ DTT and AA assays

\section{Introduction}

Many epidemiological and toxicological studies have demonstrated that oxidative stress is one of the main mechanisms by which atmospheric particles (PM) can trigger negative health effects, mediated by the generation and subsequent reactions of reactive oxygen species (ROS) and reactive nitrogen species (RNS) (Akhtar et al. 2010; Bates et al. 2015; Longhin et al. 2013; Verma et al. 2015). PM oxidative potential (OP) has been thus defined as a measure of the ability of PM components to oxidize a target molecule or to catalyze the production of ROS/RNS and consumption of antioxidants. Thus, it could represent a better metric of PM hazard exposure than

Responsible editor: Philippe Garrigues

Maria Chiara Pietrogrande mpc@unife.it

1 Department of Chemical and Pharmaceutical Sciences, University of Ferrara, Via Fossato di Mortara 17/19 - 44121, Ferrara, Italy

2 Emilia Romagna Regional Agency for Prevention, Environment and Energy, ARPAE, Via Po 5 - 40139, Bologna, Italy
PM mass concentration, as an unifying metric integrating PM chemical/physical properties and bioreactivity into one measurement (Abrams et al. 2017; Antinolo et al. 2015; Calas et al. 2017; Crobeddu et al. 2020; Fang et al. 2016; Janssen et al. 2015; Jiang et al. 2019; Øvrevik 2019; Romano et al. 2019). Among several in vitro cellular and acellular assays proposed to quantify OP, cell-free assays, besides being non-invasive, have the advantages of being fast, inexpensive, easy to organize and suitable for automation (Bates et al. 2019; Calas et al. 2018; Fang et al. 2015; Gao et al. 2017; Hedayat et al. 2014; Pietrogrande et al. 2019a; Visentin et al. 2016). They all require a preliminary solvent extraction to retrieve the PM components from the loaded filter, still conserving, as much as possible, the physical and chemical properties of the complex mixtures present in the atmosphere. This is a critic step, as the major contributors to PM toxicity are trace components, that contribute little to PM mass and may be potentially loss during the extraction process or contaminated by interfering compounds (Bein and Wexler 2015; Roper et al. 2017; Roper et al. 2019; Simonetti et al. 2018; Van Winkle et al. 2015). Although several OP assay procedures are currently in use, to date, no real consensus has emerged towards standardized protocols, including the type 
of filters used to collect atmospheric PM, solvent and extraction procedures, and OP assay media (Bates et al. 2019; Calas et al. 2017; Luo et al. 2019; Molina et al. 2020; Roper et al. 2015; Roper et al. 2017; Wiseman 2015; Yang et al. 2014). This may generate discrepancies in assay responses reducing the reliability of OP data and, hence, lessen formation of a robust consensus on the use of OP as an exposure metric for ambient air PM in epidemiological studies.

This motivates the present study, that investigates the impact of the filter solvent extraction on responses of two acellular OP assays, in order to guide selection of an extraction method that is best suited for OP assessments of ambient $\mathrm{PM}_{2.5}$ samples. The study was performed by extracting equal portions of a single $\mathrm{PM}_{2.5}$ filter with different solutions, namely, phosphate buffer and methanol, as typically used for PM extraction in OP assays and toxicological studies. In addition, the Gamble's solution was investigated, as a lung fluid surrogate mixture, that may closely mimic bio-accessibility of particle-bound species in the physiological fluids encountered during PM exposition (Calas et al. 2017; Collins et al. 2015; Leclercq et al. 2017; Luo et al. 2019; Mukhtar et al. 2015; Van Winkle et al. 2015; Wiseman 2015; Zeng et al. 2019). To date, the impact of solvent extraction on PM OP or toxicity has been studied by comparing aqueous solutions vs. organic solvents (i.e., Bein and Wexler 2015; Roper et al. 2019; Yang et al. 2014), or different simulated lung fluid surrogates (i.e., Calas et al. 2017; Leclercq et al. 2017; Van Winkle et al. 2015). To our knowledge, a comprehensive intercomparison of the three different extraction liquids has never been conducted.

Two widely used cell-free assays were investigated: the dithiothreitol (DTT) assay, which simulates PM-catalyzed electron transfer from cellular antioxidants (e.g., NADPH) to $\mathrm{O}_{2}$ and the ascorbic acid (AA) assay, based on redox reactions of AA as the most abundant antioxidant found in lung fluids, which has a vital role based on the catalytic ability of redoxactive species (Bates et al. 2019; Calas et al. 2018; Charrier and Anastasio 2015; Crobeddu et al. 2020; Fang et al. 2016; Gao et al. 2017; Hedayat et al. 2014).

The study was performed on 32 real environmental $\mathrm{PM}_{2.5}$ samples from urban and rural sites in the Po Valley (Northern Italy) in spring 2018, as well as on individual standard compounds, chosen for either their known reactivity to the DTT and AA assays or their abundance in atmospheric aerosol, i.e, metals and quinones (Charrier and Anastasio 2015; Fang et al. 2016; Fujitani et al. 2017; Pietrogrande et al. 2019a; Verma et al. 2015; Tuet et al. 2017).

The study is a part of a larger project concerning a critical investigation of the different experimental protocols generally used in OP assays, with the aim to provide useful information to design a standardized analytical protocol for increasing the reliability and overall quality of data derived from OP assays (Pietrogrande et al. 2019a; Pietrogrande et al. 2019b).

\section{Materials and methods}

\section{Reagents and standards}

Sodium phosphate $\left(\mathrm{NaH}_{2} \mathrm{PO}_{4}, \mathrm{ACS}\right)$, Magnesium chloride hexahydrate $\left(\mathrm{MgCl}_{2} \cdot 6 \mathrm{H}_{2} \mathrm{O}\right)$, sodium chloride $(\mathrm{NaCl}$, ACS), potassium chloride $(\mathrm{KCl})$, disodium hydrogen phosphate $\left(\mathrm{Na}_{2} \mathrm{HPO}_{4}\right)$, sodium Sulfate $\left(\mathrm{Na}_{2} \mathrm{SO}_{4}\right)$, calcium chloride dehydrate $\left(\mathrm{CaCl}_{2} \cdot 2 \mathrm{H}_{2} \mathrm{O}\right)$, sodium acetate, sodium hydrogen carbonate $\left(\mathrm{NaHCO}_{3}\right)$, and sodium citrate dehydrate $\left(\mathrm{C}_{6} \mathrm{H}_{5} \mathrm{O}_{7} \mathrm{Na}_{3} \cdot 2 \mathrm{H}_{2} \mathrm{O}\right)$ were from Fisher Scientific.

Standard solutions of L-ascorbic acid sodium salt (AA), (Sigma Aldrich) were prepared at $10 \mathrm{mM}$ concentration in ultrapure water (Milli-Q® IQ 7000 water purification system). Solutions of DTT and DTNB (Sigma Aldrich) were prepared in phosphate buffer (at $10 \mathrm{mM}$ ) and maintained in ice and in the dark during the experiment.

Aqueous solutions of the reagents are unstable at room temperature and sensible to light, thus they were preserved in amber glass vials in the dark at $-20{ }^{\circ} \mathrm{C}$.

Copper (II) sulfate (98\%), iron (II) chloride (ACS), 1,2naphthoquinone (1,2-NPQ, $97 \%)$, and 9,10phenanthrenequinone (9,10-PNQ, 99\%) were from SigmaAldrich and Acros Organics. Individual standard stock solutions were prepared for each analyte by weighting pure standards with a concentration of $10^{-2} \mathrm{M}$ using MilliQ water for metal ions and acetonitrile for quinones as solvent.

Methanol was HPLC grade solvent purchased from SigmaAldrich.

\section{Study sites and PM sampling}

Sampling took place at two sites in the Emilia Romagna region, in the eastern part of the Po Valley (northern Italy). The urban background site (URB) is located in the middle of the city of Bologna ( 400,000 inhabitants) in a densely populated area, and the rural background station (RUR) is located at San Pietro Capofiume, about $30 \mathrm{~km}$ northeast from the city.

From 10 March to 8 April 2018, four $\mathrm{PM}_{2.5}$ samples were simultaneously collected every day at the two sites. A low volume automatic outdoor sampler (Skypost PM, TCRTECORA Instruments, Corsico, Milan, Italy) was used, operating at the standard airflow rate of $38.3 \mathrm{~L} \mathrm{~min}^{-1}$ for $24 \mathrm{~h}$ to collect an air volume of $55 \mathrm{~m}^{3}$ per day. $\mathrm{PM}_{2.5}$ samples were collected on 47-mm diameter quartz fiber filters provided from Whatman (Whatman® QM-A quartz filters). After sampling, the procedure outlined in European Standard EN 12341 (CEN, 1998) was applied for equilibration and weighing the collected samples. All details concerning the site and the logistical aspects of the sampling procedure can be found in Authors' papers (Pietrogrande et al. 2019a; Ricciardelli et al. 2017; Visentin et al. 2016). 


\section{Extraction solvent and solutions}

The phosphate buffer $\left(\mathrm{Na}_{2} \mathrm{HPO}_{4}\right.$ and $\left.\mathrm{NaH}_{2} \mathrm{PO}_{4}\right)$ was $0.1 \mathrm{M}$ at $\mathrm{pH}$ 7.4. The Gamble's solution was prepared with magnesium chloride hexahydrate $10^{-3} \mathrm{M}$, sodium chloride $0.1 \mathrm{M}$, Potassium chloride $4 \cdot 10^{-3} \mathrm{M}$, disodium hydrogen phosphate $0.9 \cdot 10^{-3} \mathrm{M}$, sodium sulfate $0.4 \cdot 10^{-3} \mathrm{M}$, calcium chloride dehydrate $2.5 \cdot 10^{-3} \mathrm{M}$, sodium acetate $7 \cdot 10^{-3} \mathrm{M}$, sodium hydrogen carbonate $0.03 \mathrm{M}$, and sodium citrate dehydrate $0.3 \cdot 10^{-3}$ $\mathrm{M}$ in ultrapure water.

All solutions were prepared in ultrapure water (Milli-Q® IQ 7000 water purification system). Both phosphate buffer and Gamble's solution were treated with Chelex ${ }^{\circledR} 100$ sodium form resin (BioRad) to remove any metal contamination.

\section{Extraction procedures}

In our experiments, each quartz filter was divided into four parts, and three of them were extracted using each of the investigated solvents - phosphate buffer, Gamble's solution, and methanol - and then submitted to DTT and AA assays. The same procedure was also applied to quartz blank filters spiked with standard solutions of redox active compounds and then extracted with the 3 solvents and also with ultrapure Milli-Q water.

Aqueous solution extraction Water-based extractions were performed for $15 \mathrm{~min}$ in an ultrasonic bath using $10 \mathrm{~mL}$ of phosphate buffer or Gamble's solution, following the procedure previously used by Authors that has been found to guarantee a good extraction efficiency $\geq 90 \%$ (Pietrogrande et al. 2019a; Visentin et al. 2016). The extracts were then filtered on a regenerate cellulose syringe filter $(13 \mathrm{~mm}, 0.22 \mu \mathrm{m}$, Kinesis) to remove the suspended solid particles. Then, $3 \mathrm{~mL}$ of the solution were submitted to each OP assays.

Methanol extraction A quarter of filter was extracted for $15 \mathrm{~min}$ in an ultrasonic bath using $10 \mathrm{~mL}$ of methanol, following the procedure commonly used by other Authors (Bein and Wexler 2015; Gao et al. 2017; Janssen et al. 2015; Roper et al. 2017; Roper et al. 2019; Verma et al. 2015; Yang et al. 2014). The extract was then filtered on a PTFE syringe filter ( $25 \mathrm{~mm}, 0.22 \mu \mathrm{m}$, Kinesis) to remove the suspended solid particles. The filtrate was then transferred into a rounded glass flask and placed in a centrifugal vacuum concentrator (miVac, Genevac Inc, USA) to remove methanol to dryness. Then, extract was reconstituted by adding $10 \mathrm{~mL}$ of phosphate buffer, and $3 \mathrm{~mL}$ of the solution were submitted to each OP assay.

\section{DTT and AA assays for measuring oxidative potential}

Oxidative potential of the collected $\mathrm{PM}_{2.5}$ samples and standard solutions were assessed with the DTT and AA assays, following the experimental procedure described elsewhere (Perrone et al. 2019; Pietrogrande et al. 2018; Visentin et al. 2016). Briefly, both the assays were performed on $3 \mathrm{~mL}$ of the filter extract operating at a constant temperature of $37{ }^{\circ} \mathrm{C}$ using a dry bath.

Spectrophotometric measurements were performed in a UV-Vis spectrophotometer (Jasco V-730, JASCO EUROPE s.r.l.) with a $1-\mathrm{cm}$ path length optical cell. Polystyrene and quartz cuvette were used for DTT and AA assays, respectively.

In the DTT assay, $30 \mu \mathrm{l}$ of the $10 \mathrm{mM}$ DTT solution was added to the sample (i.e., time zero) and the rate of DTT depletion $\left(\mathrm{OP}^{\mathrm{DTT}}\right)$ measured as follows. At defined times, a $0.50 \mathrm{~mL}$ aliquot of the reaction mixture was removed, and the reaction stopped with trichloroacetic acid $(0.50 \mathrm{~mL}$ of $10 \%)$. Then, the remaining DTT was reacted with DTNB $\left(5,5^{\prime}\right.$ Dithiobis(2-nitrobenzoic acid)) to generate DTT-disulphide and 2-nitro-5-thiobenzoic acid (TNB): $50 \mu \mathrm{L}$ of the DTNB solution $(10 \mathrm{mM}$ concentration in phosphate buffer at $\mathrm{pH} 7.4)$ was added to each aliquots and well mixed. After 2 min to allow the complete reaction, $\mathrm{pH}$ was increased to $\mathrm{pH} 8.9$ by adding $2.0 \mathrm{~mL}$ of Tris- $\mathrm{HCl}$ buffer $(0.40 \mathrm{M}$ at $\mathrm{pH} 8.9$ with $20 \mathrm{mM}$ of EDTA) to form the mercaptide ion $\left(\mathrm{TNB}^{2-}\right.$ ), which has a high absorbance (molar extinction coefficient $\varepsilon=14150$ $\mathrm{M}^{-1} \mathrm{~cm}^{-1}$ at $412 \mathrm{~nm}$ ).

In the AA assay, $30 \mu \mathrm{l}$ of the $10 \mathrm{mM}$ AA solution was added to the sample (i.e., time zero). Then, the rate of AA depletion $\left(\mathrm{OP}^{\mathrm{AA}}\right)$ was followed directly in the spectrophotometric cuvette by measuring at defined time intervals the absorption of the ascorbate ion at $265 \mathrm{~nm}\left(\varepsilon=14500 \mathrm{M}^{-1} \mathrm{~cm}^{-1}\right.$ at $\mathrm{pH}$ 7.4).

The rate of DTT or AA depletion $\left(\mathrm{nmol} \mathrm{min}{ }^{-1}\right.$ ) was determined by linearly fitting the experimental points of the reagents concentration versus time $(5,10,15,25,40$ $\min )$. The response of blank filters was determined and subtracted from the data of real PM samples. The obtained OP responses were then normalized both to air collected volume, i.e., volume-normalized $\mathrm{OP}_{\mathrm{V}}\left(\mathrm{nmol} \mathrm{min} \mathrm{m}^{-1} \mathrm{~m}^{-3}\right.$ ), and to $\mathrm{PM}_{2.5}$ sampled mass, i.e., mass-normalized $\mathrm{OP}_{\mathrm{m}}$ $\left(\mathrm{nmol} \min ^{-1} \mu \mathrm{g}^{-1}\right)$.

\section{Chemical analysis of ambient $\mathrm{PM}_{2.5}$ samples}

Chemical composition of the $\mathrm{PM}_{2.5}$ samples was investigated, by quantifying the main tracers useful for source apportionment. Chemical analysis was performed in the laboratories of the Emilia Romagna Regional Agency for Prevention, Environment, and Energy in Ravenna (Italy), using $3 \mathrm{PM}_{2.5}$ samples simultaneously collected each day. Details are reported elsewhere (Ricciardelli et al. 2017).

Briefly, one $\mathrm{PM}_{2.5}$ filter was extracted in $10 \mathrm{ml}$ of MilliQ water, sonicated for $15 \mathrm{~min}$, filtered on $0.45-\mu \mathrm{m}$ cellulose acetate filter and then submitted to the following instrumental 
analyses. Inorganic ions were quantified by Ionic Chromatography: ICS-1000 with IonPac ${ }^{\mathrm{TM}} \mathrm{AS} 9-\mathrm{HC}$ for anions $\left(\mathrm{Cl}^{-}, \mathrm{NO}_{3}{ }^{-}, \mathrm{SO}_{4}{ }^{2-}\right)$ and ICS-1100 with IonPac ${ }^{\mathrm{TM}} \mathrm{CS} 12 \mathrm{~A}$ for cations $\left(\mathrm{K}^{+}, \mathrm{NH}_{4}{ }^{+}\right.$) (DIONEX, California, USA). Levoglucosan was quantified using HPLC-MS instrument (HPLC Agilent 1200 series and Triple Quadrupole 6410 equipped with Electrospray Ionization, Agilent Technologies Inc., CA, USA) with a ZORBAX amino column. One filter was mineralized with $10 \mathrm{ml}$ of a $\mathrm{HNO}_{3}: \mathrm{H}_{2} \mathrm{O}_{2}(8: 2)$ mixture and analyzed for metal quantification using inductively coupled plasma-mass spectrometry (7700 ICP-MS, Agilent Technologies Inc., CA, USA), following the method reported in UNI EN 14902:2005. Another filter was directly submitted to thermo-optical transmission analysis to quantify the carbonaceous fraction, i.e., elemental carbon, EC, and organic carbon, OC. A Sunset instrument (Laboratory Inc., OR, USA) was used, following the EUSAAR2 thermal protocol (Cavalli et al. 2010), according to the European standard (UNI EN 16909:2017).

\section{Statistical analysis}

The paired sample $t$ test was used to examine whether extraction solvent differed significantly for each OP assay, as well as samples collected at the urban and rural sites. A $p$ value less than 0.05 was regarded as statistically significant.

Pearson correlation analysis was performed to investigate significance of correlations among OP responses for different extraction methods as well as associations between OP responses and chemical composition.

\section{Results and discussion}

Three extraction solvents were investigated to represent the typically used protocols for OP assay of PM samples:

- phosphate buffer (PB), the most common aqueous buffer employed by the Authors (Perrone et al. 2019; Pietrogrande et al. 2018; Pietrogrande et al. 2019a; Visentin et al. 2016) and other researchers (Bates et al. 2019; Calas et al. 2018; Fang et al. 2015; Hedayat et al. 2014);

- methanol (Me), the organic solvent frequently used in $\mathrm{PM}_{2.5}$ toxicology studies, due to its ability to extract hydrophobic and hydrophilic compounds, combined with its low cost and comparatively small blank filter effect (Bein and Wexler 2015; Janssen et al. 2015; Roper et al. 2017; Roper et al. 2019; Verma et al. 2015; Yang et al. 2014);

- Gamble's solution $(\mathrm{G})$, an artificial lung fluid consisting of a mixture of salts ( $\mathrm{pH}$ : 7.4) widely used for closely simulating the real physiological conditions related to PM exposition. It is typically employed for pulmonary simulation in studies on PM toxicity, since it represents the extra-cellular fluids in the deep lung (Bein and Wexler 2015; Collins et al. 2015; Goix et al. 2016; Leclercq et al. 2017; Mukhtar et al. 2015; Wei et al. 2019; Wiseman, 2015; Xing et al. 2019; Zeng et al. 2019).

Toxicological studies suggest that biological response of particle-bound species is strongly affected by different extraction protocols, since it is strongly influenced by the degree of bio accessibility of the biologically active compounds, i.e., immediately internalized compounds can cause faster inflammation than insoluble species in lung fluids (Roper et al. 2017; Xing et al. 2019).

The different extraction methods were tested by measuring $\mathrm{OP}^{\mathrm{DTT}}$ and $\mathrm{OP}^{\mathrm{AA}}$ responses of each ambient $\mathrm{PM}_{2.5}$ filter after extraction with the three liquids and comparing the obtained results.

\section{$O P^{D T T}$ and $O P^{A A}$ responses for ambient $P M$ samples in the three extracting solutions}

The individual volume- and mass normalized $\mathrm{OP}^{\mathrm{DTT}}$ and $\mathrm{OP}^{\mathrm{AA}}$ responses were measured for each sample (Tables S1S3 in Supplementary Material), and their mean values were computed for each investigated solvent (Table 1). The mean $\mathrm{OP}_{\mathrm{V}}{ }^{\mathrm{DTT}}$ and $\mathrm{OP}_{\mathrm{V}}{ }^{\mathrm{AA}}$ responses are compared in Fig. 1a, b (light grey bars). Overall, similar OP values were measured from the different extracts, with mean $\mathrm{OP}_{\mathrm{V}}{ }^{\mathrm{DTT}}$ values ranging from $0.10 \pm 0.09$ to $0.19 \pm 0.18 \mathrm{nmol} \mathrm{min}{ }^{-1} \mathrm{~m}^{-3}$ and mean $\mathrm{OP}_{\mathrm{V}}{ }^{\mathrm{AA}}$ from $0.22 \pm 0.08$ to $0.38 \pm 0.16 \mathrm{nmol} \mathrm{min}^{-1} \mathrm{~m}^{-3}$. In general, such measured activities are at the lower end of the range usually measured for $\mathrm{PM}_{2.5}$ at Italian sites, i.e., $\sim 0.2$

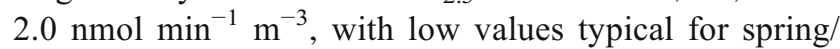
summer (Perrone et al. 2019; Pietrogrande et al. 2018; Pietrogrande et al. 2019a, b; Simonetti et al. 2018; Visentin et al. 2016).

A deeper insight into the data highlights that the OP responses varied for different extraction methods, since methanol extraction generated the lowest values and phosphate buffer the highest, following the same increasing order for both $\mathrm{OP}_{\mathrm{V}}{ }^{\mathrm{DTT}}$ and $\mathrm{OP}_{\mathrm{V}}{ }^{\mathrm{AA}}$ responses:

methanol $<$ Gamble $<$ phosphate buffer

However, given the large standard deviations of the calculated means, statistically significant difference among the solvent data (Student's $t$ test, $p<0.05$ ) was singled out only for lower methanol $\mathrm{OP}_{\mathrm{V}}{ }^{\mathrm{AA}}$ data (signified by $*$ in Fig. 1b, light grey bars). Indeed, such SDs do not reflect uncertainties in sample analysis (\% RSD $\leq 6 \%$ for all measurements), but rather variations in the $\mathrm{OP}$ responses of the real investigated $\mathrm{PM}_{2.5}$ filters. 
Table 1 Experimental parameters measured in $\mathrm{PM}_{2.5}$ particles: mean values and standard deviation (SD) computed for all the investigated samples (total, $n=32)$ and the samples collected at the urban $(n=16)$ and rural sites $(n=16)$, separately. $\mathrm{OP}^{\mathrm{DTT}}$ and $\mathrm{OP}^{\mathrm{AA}}$ responses were measured after extraction with each investigated solvent and expressed as volume-based $\mathrm{OP}_{\mathrm{V}}\left(\mathrm{nmol} \mathrm{min} \mathrm{m}^{-1} \mathrm{~m}^{-3}\right)$ and mass-based $\mathrm{OP}_{\mathrm{m}}(\mathrm{nmol}$ $\min ^{-1} \mu \mathrm{g}^{-1}$ ) values. Concentrations of chemical components are expressed in $\mathrm{ng} \mathrm{m}^{-3}$, unless differently specified. *Indicates statistically significant difference $(p<0.05)$ among the extraction solvents; ${ }^{\dagger}$ indicates statistically significant difference between urban and rural samples

\begin{tabular}{|c|c|c|c|c|c|c|}
\hline & \multicolumn{2}{|c|}{ Total $(\mathrm{n}=32)$} & \multicolumn{2}{|c|}{$\operatorname{Urban}(\mathrm{n}=16)$} & \multicolumn{2}{|l|}{ Rural $(\mathrm{n}=16)$} \\
\hline & Mean & $\mathrm{SD}$ & Mean & SD & Mean & SD \\
\hline $\mathrm{OP}_{\mathrm{V}}{ }^{\mathrm{DTT}} \mathrm{PB}\left(\mathrm{nmol} \mathrm{min}{ }^{-1} \mathrm{~m}^{-3}\right)$ & 0.19 & 0.18 & $0.41 *$ & 0.18 & $0.08 \dagger$ & 0.04 \\
\hline $\mathrm{OP}_{\mathrm{V}}^{\mathrm{DTT}} \mathrm{G}\left(\mathrm{nmol} \mathrm{min}^{-1} \mathrm{~m}^{-3}\right)$ & 0.10 & 0.09 & 0.16 & 0.08 & $0.03 \dagger$ & 0.03 \\
\hline 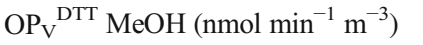 & 0.11 & 0.09 & 0.18 & 0.08 & $0.02 \dagger$ & 0.03 \\
\hline $\mathrm{OP}_{\mathrm{V}}^{\mathrm{AA}} \mathrm{PB}\left(\mathrm{nmol} \mathrm{min} \mathrm{m}^{-1} \mathrm{~m}^{-3}\right)$ & 0.38 & 0.16 & 0.47 & 0.15 & 0.30 & 0.12 \\
\hline $\mathrm{OP}_{\mathrm{V}}{ }^{\mathrm{AA}} \mathrm{G}\left(\mathrm{nmol} \mathrm{min} \mathrm{m}^{-1} \mathrm{~m}^{-3}\right)$ & 0.34 & 0.22 & 0.42 & 0.26 & 0.27 & 0.12 \\
\hline $\mathrm{OP}_{\mathrm{V}}{ }^{\mathrm{AA}} \mathrm{MeOH}\left(\mathrm{nmol} \mathrm{min}{ }^{-1} \mathrm{~m}^{-3}\right)$ & $0.22 *$ & 0.08 & $0.24 *$ & 0.08 & 0.22 & 0.14 \\
\hline $\mathrm{OP}_{\mathrm{m}}{ }^{\mathrm{DTT}} \mathrm{PB}\left(\mathrm{nmol} \mathrm{min}{ }^{-1} \mu \mathrm{g}^{-1}\right)$ & 0.014 & 0.008 & 0.023 & 0.018 & $0.002 \uparrow$ & 0.002 \\
\hline 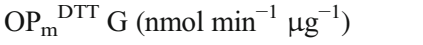 & 0.006 & 0.004 & 0.009 & 0.003 & $0.002 \uparrow$ & 0.002 \\
\hline $\mathrm{OP}_{\mathrm{m}}{ }^{\mathrm{DTT}} \mathrm{MeOH}\left(\mathrm{nmol} \mathrm{min}{ }^{-1} \mu \mathrm{g}^{-1}\right)$ & 0.006 & 0.005 & 0.010 & 0.006 & $0.001 \dagger$ & 0.001 \\
\hline $\mathrm{OP}_{\mathrm{m}}{ }^{\mathrm{AA}} \mathrm{PB}\left(\mathrm{nmol} \mathrm{min}{ }^{-1} \mu \mathrm{g}^{-1}\right)$ & 0.027 & 0.015 & 0.031 & 0.016 & 0.024 & 0.013 \\
\hline $\mathrm{OP}_{\mathrm{m}}{ }^{\mathrm{AA}}$ Gamble $\left(\mathrm{nmol} \mathrm{min} \mathrm{mig}^{-1}\right)$ & 0.023 & 0.013 & 0.026 & 0.013 & 0.021 & 0.013 \\
\hline $\mathrm{OP}_{\mathrm{m}}{ }^{\mathrm{AA}} \mathrm{MeOH}\left(\mathrm{nmol} \mathrm{min}{ }^{-1} \mu \mathrm{g}^{-1}\right)$ & 0.013 & 0.012 & 0.012 & 0.009 & 0.016 & 0.015 \\
\hline $\mathrm{PM}_{2.5}\left(\mu \mathrm{g} \mathrm{m}^{-3}\right)$ & 15.32 & 4.67 & 16.81 & 5.19 & $13.83 \dagger$ & 3.66 \\
\hline $\mathrm{OC}\left(\mu \mathrm{g} \mathrm{m}^{-3}\right)$ & 3.95 & 1.41 & 4.42 & 1.49 & 3.48 & 1.14 \\
\hline $\mathrm{EC}\left(\mu \mathrm{g} \mathrm{m}^{-3}\right)$ & 0.79 & 0.41 & 1.04 & 0.43 & $0.54 \dagger$ & 0.17 \\
\hline Levoglucosano & 117.81 & 60.69 & 135.18 & 52.75 & 100.44 & 63.10 \\
\hline $\mathrm{NH}_{4}^{+}\left(\mu \mathrm{g} \mathrm{m}^{-3}\right)$ & 1.83 & 0.72 & 1.93 & 0.77 & 1.74 & 0.66 \\
\hline $\mathrm{K}^{+}$ & 84.69 & 43.87 & 92.50 & 42.20 & 76.88 & 44.12 \\
\hline $\mathrm{Cl}^{-}$ & 70.63 & 88.14 & 141.25 & 74.57 & $<\mathrm{LOD} \dagger$ & - \\
\hline $\mathrm{NO}_{3}^{-}\left(\mu \mathrm{g} \mathrm{m}^{-3}\right)$ & 3.43 & 1.65 & 3.74 & 1.76 & 3.12 & 1.46 \\
\hline $\mathrm{SO}_{4}^{2-}\left(\mu \mathrm{g} \mathrm{m}^{-3}\right)$ & 1.54 & 0.81 & 1.65 & 0.81 & 1.42 & 0.80 \\
\hline Metals & 91.89 & 144.16 & 166.46 & 82.56 & $26.65 \dagger$ & 16.14 \\
\hline $\mathrm{Fe}$ & 80.84 & 123.03 & 128 & 58.38 & $33.68 \dagger$ & 27.24 \\
\hline $\mathrm{Mn}$ & 1.89 & 1.32 & 2.49 & 1.63 & 1.33 & 0.48 \\
\hline $\mathrm{Zn}$ & 0.46 & 0.69 & $<$ LOD & - & 0.92 & 0.73 \\
\hline $\mathrm{Pb}$ & 4.58 & 5.60 & 10.21 & 3.52 & $<\mathrm{LOD} \uparrow$ & - \\
\hline V & 1.89 & 1.23 & 2.33 & 1.48 & $1.47 \dagger$ & 0.69 \\
\hline
\end{tabular}

\section{Comparison between urban and rural PM samples}

Then, data from filters collected at the urban (URB, $n=16$ ) and rural (RUR, $n=16$ ) sites were separated and investigated in detail. The objective was not to compare the different locations, but rather to explore the effect of solvent extraction on OP of PM samples with different chemical compositions. The mean and SD values of volume-based $\mathrm{OP}^{\mathrm{DTT}}$ and $\mathrm{OP}^{\mathrm{AA}}$ responses computed on the two groups are reported in (Table 1) and shown in Fig. 1a, b for comparison.

The two separated groups showed the same general solvent extraction trend, even with magnified differences for the URB compared with RUR samples. In fact, for URB samples, $\mathrm{OP}_{\mathrm{V}}{ }^{\mathrm{DTT}}$ responses with $\mathrm{PB}$ were nearly double that those with the other solvents (significant differences indicated by $*$ in
Fig. 1a). Otherwise, the RUR group showed almost constant $\mathrm{OP}_{\mathrm{V}}{ }^{\mathrm{DTT}}$ and $\mathrm{OP}_{\mathrm{V}}{ }^{\mathrm{AA}}$ data, nearly independent of the extraction conditions (Tables S1 and S2 in Supplementary Material). By comparing the $\mathrm{OP}_{\mathrm{V}}{ }^{\mathrm{DTT}}$ and $\mathrm{OP}_{\mathrm{V}}{ }^{\mathrm{AA}}$ values measured at the two sites in detail, we can observe different behaviors of the two OP assays.

Overall, the $\mathrm{OP}_{\mathrm{V}}{ }^{\mathrm{DTT}}$ values measured in Bologna are significantly higher $(p<0.05, \uparrow$ in Table 1$)$ than those at the rural site, for each investigated solvent. Such differences may be mainly ascribed to variations in $\mathrm{PM}_{2.5}$ mass concentration, that follow the same trend with higher mean values at URB than at RUR sites, i.e., $16.8 \pm 5.2 \mu \mathrm{g} \mathrm{m}^{-3}$ and $13.8 \pm 3.7 \mu \mathrm{g}$ $\mathrm{m}^{-3}$, respectively (Table 1 and Fig. 1a, b).

In addition, they may be generated from differences in the PM intrinsic oxidative properties, quantified by mass-related 


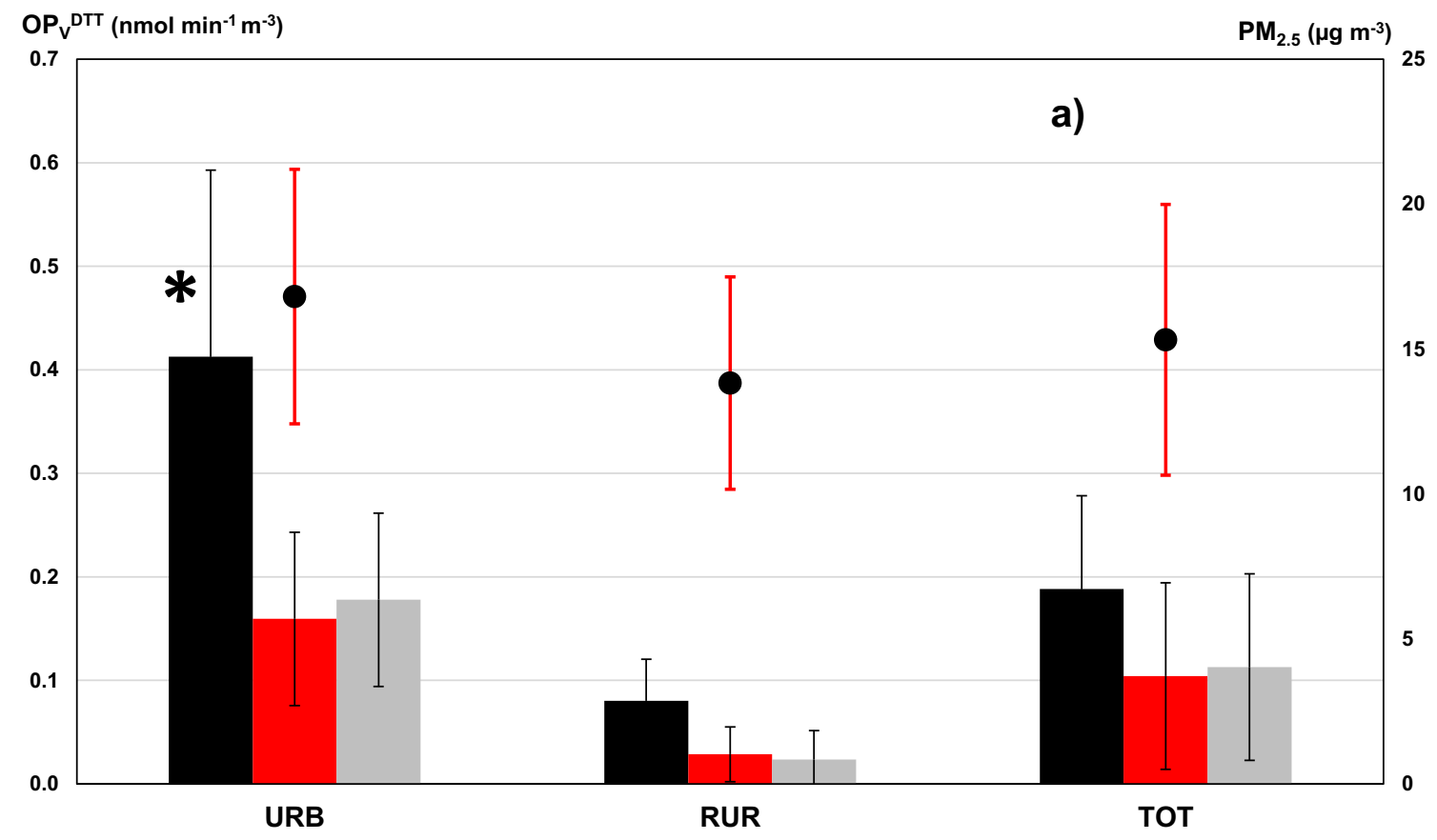

口B $\backsim$ Gamble $\backsim \mathrm{MeOH} \bullet \mathrm{PM} 2.5$

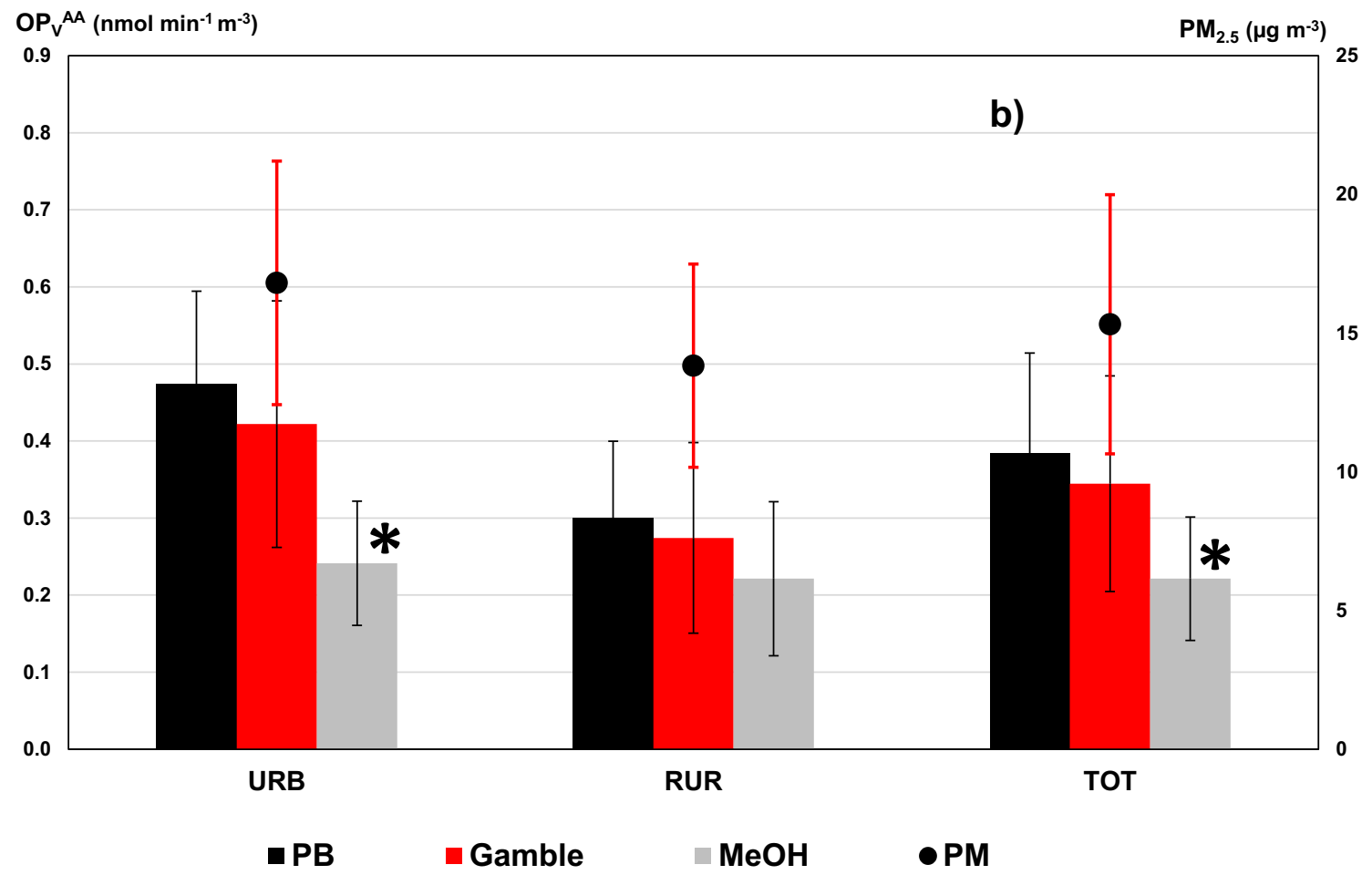

Fig. 1 Comparison among $\mathrm{OP}_{\mathrm{V}}$ responses using different extraction solvents. Mean values were computed on all the investigated $\mathrm{PM}_{2.5}$ samples, as well as on urban and rural samples, separately. Error bars denote 1 standard deviation. *indicates statistical significance at $p<0.05$

level. Black bars: phosphate buffer; red bars: Gamble's solution; light grey bars: methanol. a. Comparison among $\mathrm{OP}_{\mathrm{V}}{ }^{\mathrm{DTT}}$ responses. b Comparison among $\mathrm{OP}_{\mathrm{V}}{ }^{\mathrm{AA}}$ responses.

$\mathrm{OP}_{\mathrm{m}}{ }^{\mathrm{DTT}}$ parameter (Table 1 and S3). In fact, these values are significantly $(p<0.05)$ higher at URB (from $0.009 \pm 0.003$ to $0.023 \pm 0.018 \mathrm{nmol} \mathrm{min}{ }^{-1} \mu \mathrm{g}^{-1}$ ) compared with RUR site

(from $0.001 \pm 0.001$ to $0.002 \pm 0.002 \mathrm{nmol} \mathrm{min}^{-1} \mu \mathrm{g}^{-1}$ ) (Table S3). Such a difference may be ascribed to likely higher concentrations of redox-active PM components at the urban 
site (Pietrogrande et al. 2018; Pietrogrande et al. 2019a, b; Simonetti et al. 2018; Visentin et al. 2016).

On the contrary, the measured $\mathrm{OP}^{\mathrm{AA}}$ responses, both volume- and mass-related values, do not show any significant difference between the two sites (Tables S1-S3). This is consistent with several literature papers reporting that the AA assay reactivity is less dependent on PM mass concentration as well as on chemical composition than the DTT response (Bates et al. 2019; Calas et al. 2018; Fang et al. 2016; Hedayat et al. 2014; Janssen et al. 2015; Perrone et al. 2019; Pietrogrande et al. 2019a; Visentin et al. 2016).

It is noteworthy that such difference/similarity pattern between the sites is the same for the three extraction protocols, suggesting the independence of the solvent type.

\section{Correlations between OP responses: effect of the extracting solutions and of different assays}

To highlight the effect of the extraction solvent on OP responses of different samples, the intercorrelation between OP data measured after each extraction procedure was explored by Pearson correlation analysis on the whole dataset

Table 2 Pearson inter-correlation coefficients of $\mathrm{OP}_{\mathrm{V}}\left(\mathrm{nmol} \mathrm{min}^{-1} \mathrm{~m}^{-3}\right)$ responses with concentration of $\mathrm{PM}_{2.5}$ mass and chemical components for all $\mathrm{PM}_{2.5}$ samples. $\mathrm{OP}_{\mathrm{V}}$ were measured after extraction with phosphate buffer, Gamble's solution, and methanol. Concentrations of
(Table 2) and by separately investigating URB and RUR samples (Tables S4 and S5).

Overall, all the $\mathrm{OP}_{\mathrm{V}}{ }^{\mathrm{DTT}}$ responses obtained with the different solvents resulted significantly inter-correlated (Pearson coefficient at $p \leq 0.01$, Table 2), and $\mathrm{OP}_{\mathrm{V}}{ }^{\text {DTT }}$ with Gamble and $\mathrm{MeOH}$ extraction showed linear relationships $\left(R^{2} \geq 0.84\right)$ with that with PB (Fig. 2). This highlights that the various extraction solvents have similar effects on the DTT reactivity for all the samples, and thus they all may be likely used for $\mathrm{OP}^{\mathrm{DTT}}$ assessment. However, the data plotted in Fig. 2 clearly show that the $\mathrm{OP}_{\mathrm{V}}{ }^{\mathrm{DTT}}$ responses after PB extraction were nearly double and with larger variation range than the others, so that the slope values of the best fitting straight lines are close to 0.4. Therefore, we can conclude that, among the investigated solvents, the phosphate buffer is the best solvent to choose, as it provides the highest extraction efficiency and thus the most sensible measures.

Otherwise, $\mathrm{OP}_{\mathrm{V}}{ }^{\mathrm{AA}}$ responses showed weaker correlations among the data with different solvents, with no significant correlation between Gamble and $\mathrm{MeOH}$ extraction for the whole data set (Table 2) and the URB samples (Table S4). This suggests that the investigated solvents

chemical components are expressed in $\mathrm{ng} \mathrm{m}^{-3}$, unless differently specified. Significant $r$ values based on a two-tailed $t$ test $(n=32)$ are reported in bold (at $\boldsymbol{p}$ level $<\mathbf{0 . 0 1}$ ) and in italic (at $p$ level $<0.05$ )

\begin{tabular}{|c|c|c|c|c|c|c|}
\hline & $\begin{array}{l}\mathrm{OP}_{\mathrm{V}}{ }^{\mathrm{DTT}} \\
\mathrm{PB}\end{array}$ & $\begin{array}{l}\mathrm{OP}_{\mathrm{V}}{ }^{\mathrm{DTT}} \\
\mathrm{G}\end{array}$ & $\mathrm{OP}_{\mathrm{V}}{ }^{\mathrm{DTT}} \mathrm{MeOH}$ & $\begin{array}{l}\mathrm{OP}_{\mathrm{V}}{ }^{\mathrm{AA}} \\
\mathrm{PB}\end{array}$ & $\begin{array}{l}\mathrm{OP}_{\mathrm{V}}^{\mathrm{AA}} \\
\mathrm{G}\end{array}$ & $\mathrm{OP}_{\mathrm{V}}{ }^{\mathrm{AA}} \mathrm{MeOH}$ \\
\hline $\mathrm{OP}_{\mathrm{V}}{ }^{\mathrm{DTT}} \mathrm{PB}\left(\mathrm{nmol} \mathrm{min} \mathrm{m}^{-1} \mathrm{~m}^{-3}\right)$ & 1.00 & & & & & \\
\hline $\mathrm{OP}_{\mathrm{V}}{ }^{\mathrm{DTT}} \mathrm{G}\left(\mathrm{nmol} \mathrm{min} \mathrm{m}^{-1} \mathrm{~m}^{-3}\right)$ & 0.683 & 1.00 & & & & \\
\hline $\mathrm{OP}_{\mathrm{V}}{ }^{\mathrm{DTT}} \mathrm{MeOH}\left(\mathrm{nmol} \mathrm{min} \mathrm{m}^{-1} \mathrm{~m}^{-3}\right)$ & 0.945 & 0.807 & 1.00 & & & \\
\hline $\mathrm{OP}_{\mathrm{V}}^{\mathrm{AA}} \mathrm{PB}\left(\mathrm{nmol} \mathrm{min} \mathrm{m}^{-1} \mathrm{~m}^{-3}\right)$ & 0.175 & 0.382 & 0.226 & 1.00 & & \\
\hline $\mathrm{OP}_{\mathrm{V}}^{\mathrm{AA}} \mathrm{G}\left(\mathrm{nmol} \mathrm{min} \mathrm{m}^{-1}\right)$ & 0.162 & 0.387 & 0.255 & 0.605 & 1.00 & \\
\hline $\mathrm{OP}_{\mathrm{V}}{ }^{\mathrm{AA}} \mathrm{MeOH}\left(\mathrm{nmol} \mathrm{min} \mathrm{m}^{-1} \mathrm{~m}^{-3}\right)$ & 0.113 & 0.148 & 0.155 & 0.456 & 0.431 & 1.00 \\
\hline $\mathrm{PM}_{2.5}\left(\mu \mathrm{g} \mathrm{m}^{-3}\right)$ & 0.541 & 0.770 & 0.651 & 0.253 & 0.305 & 0.075 \\
\hline $\mathrm{OC}\left(\mu \mathrm{g} \mathrm{m}^{-3}\right)$ & 0.423 & 0.674 & 0.554 & 0.227 & 0.390 & -0.045 \\
\hline $\mathrm{EC}\left(\mu \mathrm{g} \mathrm{m}^{-3}\right)$ & 0.507 & 0.781 & 0.631 & 0.486 & 0.532 & 0.161 \\
\hline Levoglucosan & 0.359 & 0.376 & 0.427 & 0.161 & 0.430 & -0.118 \\
\hline $\mathrm{NH}_{4}^{+}\left(\mu \mathrm{g} \mathrm{m}^{-3}\right)$ & 0.307 & 0.361 & 0.371 & -0.136 & 0.059 & -0.051 \\
\hline $\mathrm{K}^{+}$ & 0.319 & 0.419 & 0.421 & -0.012 & 0.387 & 0.011 \\
\hline $\mathrm{Cl}^{-}$ & 0.471 & 0.402 & 0.472 & 0.454 & 0.324 & -0.137 \\
\hline $\mathrm{NO}_{3}^{-}\left(\mu \mathrm{g} \mathrm{m}^{-3}\right)$ & 0.240 & 0.360 & 0.305 & 0.002 & 0.045 & -0.065 \\
\hline $\mathrm{SO}_{4}^{2-}\left(\mu \mathrm{g} \mathrm{m}^{-3}\right)$ & 0.452 & 0.379 & 0.496 & -0.186 & 0.076 & 0.114 \\
\hline Total Metals & 0.239 & 0.643 & 0.399 & 0.114 & 0.156 & 0.245 \\
\hline $\mathrm{Fe}$ & 0.335 & 0.539 & 0.423 & 0.280 & 0.222 & 0.296 \\
\hline $\mathrm{Mn}$ & 0.363 & 0.609 & 0.473 & 0.293 & 0.290 & 0.442 \\
\hline $\mathrm{Zn}$ & 0.083 & 0.442 & 0.232 & 0.428 & 0.420 & 0.264 \\
\hline $\mathrm{Pb}$ & 0.268 & 0.871 & 0.755 & 0.498 & 0.480 & 0.292 \\
\hline $\mathrm{V}$ & 0.432 & 0.473 & 0.675 & -0.033 & 0.025 & 0.050 \\
\hline
\end{tabular}




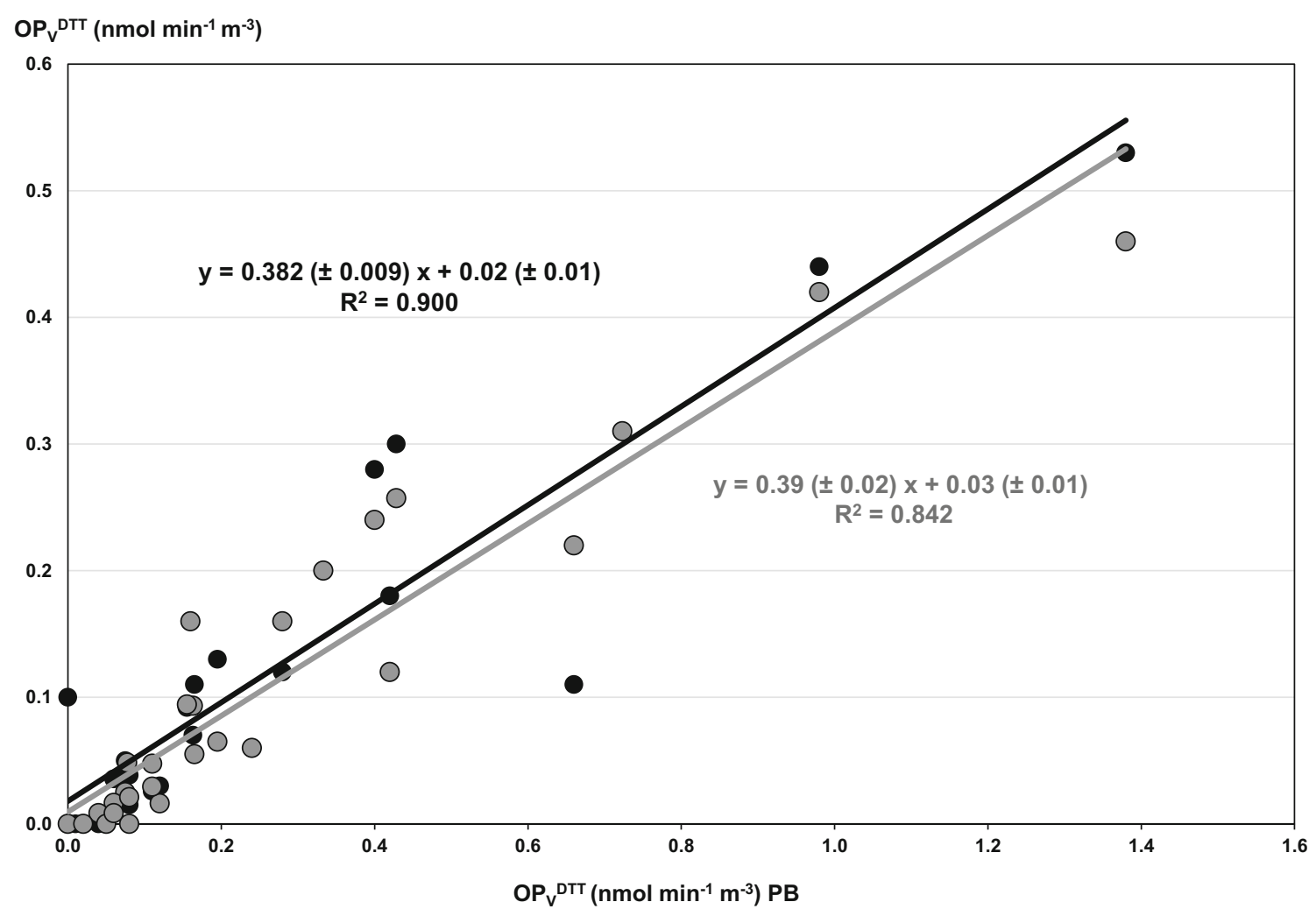

Fig. 2 Correlation between $\mathrm{OP}_{\mathrm{V}}{ }^{\mathrm{DTT}}$ responses of all the investigated $\mathrm{PM}_{2.5}$ samples after different extraction procedures: linear relationships between Gamble (light grey points and line) and $\mathrm{MeOH}$ (black points and line) compared with PB extractions. Insets: equations of the best fitting straight lines

yielded different extraction recovery of the components mostly effective towards the AA assay, that are mainly vehicle metals from traffic source (Calas et al. 2018; Charrier and Anastasio 2015; Crobeddu et al. 2020; Fang et al. 2016; Janssen et al.2015; Pietrogrande et al. 2019a; Simonetti et al. 2018; Velali et al. 2016). This is consistent with the finding that the $\mathrm{OP}_{\mathrm{V}}{ }^{\mathrm{AA}}$ responses with the different solvents were significant inter-correlated for the RUR samples $(p<0.01$, Table S5), where the contribution of redox-active metals is less dominant.

Furthermore, in order to investigate the specific role of the extraction procedure on each OP assay, the intercorrelation between $\mathrm{OP}_{\mathrm{V}}{ }^{\mathrm{DTT}}$ and $\mathrm{OP}_{\mathrm{V}}{ }^{\mathrm{AA}}$ responses was explored for each extraction procedure. No significant correlation was found between the responses of the two assays in all the data set (Table 2) and by separately investigating URB and RUR samples (Tables S4 and S5). This confirms the finding that the two OP assays display different sensitivity towards the same redox-active species present in PM, because they capture the redox reactions of different species (Bates et al. 2019; Calas et al. 2018; Charrier and Anastasio 2015; Fang et al. 2016; Janssen et al. 2015; Jiang et al. 2019; Simonetti et al. 2018), although also contrasting results are reported in literature on the topic (Bates et al. 2019; Pietrogrande et al. 2019a; Visentin et al. 2016).

\section{$O P^{D T T}$ and $O P^{A A}$ responses of individual redox-active species}

The study was extended to laboratory solutions of individual redox active species, in order to support explanation of the obtained results with experimental data and integrate hypotheses derived from the literature (Bein and Wexler 2015; Roper et al. 2019; Yang et al. 2014). The rate of DTT and AA loss was assessed for both standard solutions and spiked blank filters in the three extracting conditions, also extending to ultrapure Milli-Q water, as a control solvent. Among the four tested compounds, two were quinones, namely 9,10phenantrenequinone $(9,10-\mathrm{PNQ})$, that has been found by far the most reactive quinone to DTT assay, followed by 1,2naphthoquinone (1,2-NPQ). Others were two metals, showing high activity in AA oxidation, mainly the most reactive $\mathrm{Cu}$, followed by Fe, that is the most abundant metal in PM (Calas et al. 2018; Charrier and Anastasio 2015; Simonetti et al. 2018; Tuet et al. 2017; Verma et al. 2015). Different concentrations of standard compounds were tested to represent the range of atmospheric concentrations and obtain comparable OP responses with those from real PM samples (Pietrogrande et al. 2019a; Visentin et al. 2016). The results obtained for each individual species (mean values $\pm \mathrm{SD}, n \geq 3$ ) are reported in Table 3. 
Table $3 \mathrm{OP}^{\mathrm{DTT}}$ and $\mathrm{OP}^{\mathrm{AA}}$ responses (depletion rate $\mathrm{nmol} \mathrm{min}^{-1}$ ) of standard solutions of redox-active species. OP assays were performed in pure water, phosphate buffer and Gamble's solution media on the laboratory solutions and after extraction with different solvents on spiked blank quartz filters. For each species, measurements were repeated at least 3 times (mean and standard deviation, $n \geq 3$ )

\begin{tabular}{|c|c|c|c|c|c|c|c|}
\hline \multicolumn{4}{|l|}{$\mathbf{O} \mathbf{P}^{\mathbf{D T T}}\left(\mathrm{nmol} \mathrm{min}{ }^{-1}\right)$} & \multicolumn{4}{|c|}{$\mathbf{O P}^{\mathbf{A A}}\left(\mathrm{nmol} \min ^{-1}\right)$} \\
\hline Standard solution & Pure water & Phosphate buffer & Gamble's solution & $\begin{array}{l}\text { Standard } \\
\text { solution }\end{array}$ & Pure water & Phosphate buffer & Gamble's solution \\
\hline $\begin{array}{l}\mathrm{Cu}^{2+} \\
(1 \mu \mathrm{M})\end{array}$ & $3.49 \pm 0.12$ & $3.33 \pm 0.19$ & $2.49 \pm 0.14 *$ & $\begin{array}{l}\mathrm{Cu}^{2+} \\
(0.17 \mu \mathrm{M})\end{array}$ & $5.42 \pm 0.24$ & $5.31 \pm 0.31$ & $4.49 \pm 0.27$ \\
\hline $\mathrm{Fe}^{2+}(1 \mu \mathrm{M})$ & $0.52 \pm 0.03$ & $0.48 \pm 0.03$ & $0.34 \pm 0.03$ & $\begin{array}{l}\mathrm{Fe}^{2+} \\
(1 \mu \mathrm{M})\end{array}$ & $1.12 \pm 0.06$ & $1.07 \pm 0.06$ & $0.97 \pm 0.06$ \\
\hline 1,2-NPQ $(0.5 \mu \mathrm{M})$ & $1.92 \pm 0.09$ & $1.82 \pm 0.11$ & $1.13 \pm 0.07 *$ & $\begin{array}{l}1,2-\mathrm{NPQ} \\
(0.5 \mu \mathrm{M})\end{array}$ & $4.95 \pm 0.25$ & $4.81 \pm 0.28$ & $3.91 \pm 0.21$ \\
\hline 9,10-PNQ $(0.17 \mu \mathrm{M})$ & $1.42 \pm 0.06$ & $1.38 \pm 0.08$ & $1.26 \pm 0.07$ & $\begin{array}{l}9,10-\mathrm{PNQ} \\
(1 \mu \mathrm{M})\end{array}$ & $0.91 \pm 0.05$ & $0.91 \pm 0.06$ & $0.60 \pm 0.03 *$ \\
\hline \multicolumn{8}{|l|}{ 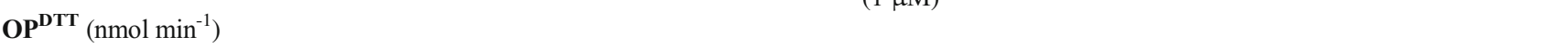 } \\
\hline Spiked blank filters & Pure water & Phosphate buffer & Gamble's solution & Methanol & & & \\
\hline $\mathrm{Cu}^{2+}(0.5 \mu \mathrm{M})$ & $1.93 \pm 0.10$ & $1.84 \pm 0.11$ & $1.21 \pm 0.09 *$ & $0.23 \pm 0.02 *$ & & & \\
\hline $\mathrm{Fe}^{2+}(1 \mu \mathrm{M})$ & $0.58 \pm 0.04$ & $0.55 \pm 0.04$ & $0.38 \pm 0.03$ & ND & & & \\
\hline 1,2-NPQ $(0.5 \mu \mathrm{M})$ & $1.20 \pm 0.07$ & $1.17 \pm 0.08$ & $0.75 \pm 0.05 *$ & $1.41 \pm 0.11^{*}$ & & & \\
\hline 9,10-PNQ $(0.17 \mu \mathrm{M})$ & $1.05 \pm 0.08$ & $1.06 \pm 0.09$ & $0.95 \pm 0.04$ & $1.65 \pm 0.12 *$ & & & \\
\hline \multicolumn{8}{|l|}{$\mathbf{O P} \mathbf{P}^{\mathbf{A A}}\left(\mathrm{nmol} \min ^{-1}\right)$} \\
\hline Spiked blank filters & Pure water & Phosphate buffer & Gamble's solution & Methanol & & & \\
\hline $\mathrm{Cu}^{2+}(0.5 \mu \mathrm{M})$ & $4.02 \pm 0.25$ & $4.76 \pm 0.28$ & $4.35 \pm 0.26$ & ND & & & \\
\hline $\mathrm{Fe}^{2+}(1 \mu \mathrm{M})$ & $1.25 \pm 0.08$ & $1.29 \pm 0.09$ & $1.12 \pm 0.06$ & ND & & & \\
\hline 1,2-NPQ $(0.5 \mu \mathrm{M})$ & $3.52 \pm 0.19$ & $3.62 \pm 0.23$ & $2.95 \pm 0.15 *$ & $4.87 \pm 0.38^{*}$ & & & \\
\hline 9,10-PNQ $(0.17 \mu \mathrm{M})$ & $0.85 \pm 0.03$ & $0.78 \pm 0.05 *$ & $0.53 \pm 0.01$ & $1.38 \pm 0.08 *$ & & & \\
\hline
\end{tabular}

$N D$ OP response lower than that of the blank quartz filter

First, the effect of the medium assay was investigated for the three aqueous solutions on each individual standard by measuring $\mathrm{OP}^{\mathrm{DTT}}$ and $\mathrm{OP}^{\mathrm{AA}}$ responses. Overall, similar results were obtained suggesting that the choice of the aqueous solution had no significant effect on the DTT and AA assay reactivity. We only observed a significant effect ( $p<0.05$, indicated by asterisk in the Table 3 ) for the Gamble's solution, with a lower $\mathrm{OP}^{\mathrm{DTT}}$ for $\mathrm{Cu}^{2+}$ and 1,2-NPQ and a lower $\mathrm{OP}^{\mathrm{AA}}$ for 9,10-PNQ. Consistent with our results, the detailed investigation of Calas (Calas et al. 2017) ascribed a similar OP ${ }^{\mathrm{DTT}}$ trend to the presence in $\mathrm{G}$ of complexing anions (orthophosphates, carbonates, acetates) and functional groups (carboxyl from glycine, citrate, and amines from glycine), that may chelate metals and thus reduce their availability to redox reactions. They also found a similar $G$ decreasing effect on quinones, that was unexpected, as organic compounds do not form strong complexes with chelating species. As likely explanation, they suggested that the Gamble medium may be less favorable to electron transfer than simpler aqueous solutions and/or that quinones may be transformed during the extraction step and storage. The trend of $\mathrm{OP}^{\mathrm{AA}}$ responses, with lower values in $\mathrm{G}$ than in $\mathrm{PB}$, is consistent with the previous Authors' results, showing that $\mathrm{OP}^{\mathrm{AA}}$ values decreased by adding further components to the phosphate buffer (Pietrogrande et al. 2019b).

\section{Explanation of effects of extracting solutions on $O P_{v}{ }^{D T T}$ and $O P_{v}{ }^{A A}$ responses}

\section{Effect of the extracting solutions: comparison among aqueous solutions}

Then, the role of the three aqueous solutions was investigated by extracting blank filters spiked with laboratory standards, in order to explain the specific effect of each extraction procedure on metals and quinones. The obtained $\mathrm{OP}^{\mathrm{DTT}}$ and $\mathrm{OP}^{\mathrm{AA}}$ values confirmed the above described trend, with nearly the same OP responses measured with pure water and phosphate buffer, that were higher than those with Gamble's solution. Indeed, we observed a significant difference $(p<0.05$, indicated by asterisk in the Table 3) only for $\mathrm{OP}^{\mathrm{DTT}}$ of $\mathrm{Cu}^{2+}$ and 1,2-NPQ and for $\mathrm{OP}^{\mathrm{AA}}$ of 1,2-NPQ and 9,10-PNQ. This may be ascribed to the dominant role of chelating agents in $\mathrm{G}$ medium in inhibiting DTT and AA depletion rate (Calas et al. 2017; Pietrogrande et al. 2019b). Otherwise, it must be underlined that such $\mathrm{G}$ complexing components can also 
display an opposite effect of increasing OP responses, as they are able to extract larger fractions of metal content from the filter, according to their chelating strengths (Collins et al. 2015; Leclercq et al. 2017; Luo et al. 2019; Mukhtar et al. 2015; Wiseman, 2015). Therefore, the overall variation may be ascribed to the combination of two contrasting contributions, namely solvent extraction efficiency to retrieve redoxactive components into solution and reactivity of individual species in the two assay media. This may be likely the reason why the $\mathrm{OP}_{\mathrm{V}}{ }^{\mathrm{AA}}$ variations for $\mathrm{Cu}$ and $\mathrm{Fe}$ are weaker than those of $\mathrm{OP}_{\mathrm{V}}{ }^{\mathrm{DTT}}$ ( $\mathrm{G}$ nearly $67 \%$ of $\mathrm{PB}$ ), as the AA assay is more sensitive to the possible larger metal content extracted by the Gamble's solution.

\section{Effect of the extracting solutions: methanol vs. aqueous solutions}

Finally, the effect of the aqueous extraction media was compared to that of methanol by measuring $\mathrm{OP}^{\mathrm{DTT}}$ and $\mathrm{OP}^{\mathrm{AA}}$ of blank filters spiked with laboratory standards, after extraction with the four solvents. Our experimental results clearly show that, compared with the used aqueous solutions, methanol extraction yielded significantly higher (at $p<0.05$, asterisk in Table 3) DTT and AA responses for quinones and lower for $\mathrm{Cu}$ and $\mathrm{Fe}$. Such a trend may be ascribed to variation in the extraction efficiency of the solvents, consistent with the decreased solubility of metal ions in $\mathrm{MeOH}$ compared with water solutions (Roper et al. 2019; Wei et al. 2019; Xing et al. 2019). Furthermore, $\mathrm{MeOH}$ has been found more effective than water to retrieve DTT reactive organic components, mainly oxidized organics (Bein and Wexler 2015; Gao et al. 2017; Janssen et al. 2015; Roper et al. 2017; Roper et al. 2019; Verma et al. 2015; Yang et al. 2014).

Overall, in our study, the $\mathrm{OP}_{\mathrm{V}}{ }^{\mathrm{DTT}}$ and $\mathrm{OP}_{\mathrm{V}}{ }^{\mathrm{AA}}$ values of $\mathrm{MeOH}$ extracts of real samples were lower than those of $\mathrm{PB}$ extracts and like those of $\mathrm{G}$ extracts, with magnified differences for the urban samples. This pattern resembles that of metals, suggesting that the oxidative properties of our real samples are mainly driven by transition metals, among the redox-active species. Such a conclusion is also consistent with the finding that all the samples showed higher responses of the AA assay, that is more sensible to metals than the DTT assay (Bates et al. 2019; Calas et al. 2018; Fang et al. 2016; Janssen et al. 2015; Pietrogrande et al. 2019a; Simonetti et al. 2018; Visentin et al. 2016). The predominant role of metals, mainly more abundant iron, in the PM oxidative properties is consistent with several literature data (Charrier and Anastasio 2015; Crobeddu et al. 2020; Perrone al. 2019; Pietrogrande et al. 2019a; Simonetti et al. 2018; Velali et al. 2016; Wei et al. 2019). However, caution must be exercised when interpreting such results, since the current study dataset lacked the $\mathrm{Cu}$ concentration, that is one of the most sensitive metals driving OP responses, mainly those of the AA assay.

\section{Correlation between OP responses in different extraction solutions and PM chemical constituents}

In addition to $\mathrm{OP}$ responses, $\mathrm{PM}_{2.5}$ mass concentrations and selected chemical components were measured for each $\mathrm{PM}_{2.5}$ sample, i.e., organic and elemental carbon, secondary ions, and some soluble transition metals (Tables S1 and S2 in Supplementary material). From the individual data, the mean and SD values were computed for all the samples and for urban and rural filters, separately (Table 1). The Student's $t$ test was applied to single out significant $(p<0.05)$ differences between sites (indicated by $\uparrow$ in Table 1). Among the investigated parameters, higher values were measured at the URB than at RUR site for $\mathrm{PM}_{2.5}$ mass $\left(16.8 \pm 5.2 \mu \mathrm{g} \mathrm{m}^{-3}\right.$ vs. $13.8 \pm$ $\left.3.7 \mu \mathrm{g} \mathrm{m}^{-3}\right)$, EC $\left(1.04 \pm 0.43 \mu \mathrm{g} \mathrm{m}^{-3}\right.$ vs. $\left.0.54 \pm 0.17 \mu \mathrm{g} \mathrm{m}^{-3}\right)$, total metals $\left(166 \pm 82 \mathrm{ng} \mathrm{m}^{-3}\right.$ vs. $\left.26.6 \pm 16.1 \mathrm{ng} \mathrm{m}^{-3}\right)$, and iron $\left(128 \pm 58 \mathrm{ng} \mathrm{m}^{-3}\right.$ vs. $\left.33.6 \pm 27 \mathrm{ng} \mathrm{m}^{-3}\right)$, as indicated by $\dagger$ in Table 1. This is consistent with a higher impact from anthropogenic source emissions at the urban site, mainly related to traffic, as previously found by the Authors at the same sites (Pietrogrande et al. 2016; Pietrogrande et al. 2019a, b).

The correlation analysis was performed to associate $\mathrm{OP}_{\mathrm{V}}$ response with $\mathrm{PM}_{2.5}$ chemical composition with the main aim to highlight if the different extraction conditions may vary such associations. Overall, the obtained results showed similar behavior for the three investigated solvents, suggesting no major impact of the extraction solvent on these correlations (Table 2). In general, $\mathrm{OP}_{\mathrm{V}}{ }^{\mathrm{DTT}}$ data resulted more widely correlated with several $\mathrm{PM}$ components, including $\mathrm{PM}_{2.5}$ mass concentration, compared with $\mathrm{OP}_{\mathrm{V}}{ }^{\mathrm{AA}}$. Consistently with other papers, DTT assay mainly responded to the organic compounds, traced by OC and EC $(p<0.01)$, that represent fuel vehicular (EC) and biomass burning emissions (Levoglucosan and $\mathrm{K}, p<0.05)$, and also to secondary atmospheric processes, traced by $\mathrm{NH}_{4}{ }^{+}, \mathrm{NO}_{3}{ }^{-}$and $\mathrm{SO}_{4}{ }^{2-}$ ions $(p<0.05)$. In addition, $\mathrm{OP}_{\mathrm{V}}{ }^{\mathrm{DTT}}$ responses resulted correlated with traffic-related metals, mainly non-exhaust traffic emissions, such as $\mathrm{Fe}, \mathrm{Mn}$, $\mathrm{Zn}$, and $\mathrm{Pb}(p<0.01)$. By separating URB and RUR samples, we can observe that the $\mathrm{OP}_{\mathrm{V}}{ }^{\text {DTT }}$ values of the URB site are more strongly associated with metals, while those at the RUR site with OC and EC (Tables S4 and S5). This is consistent with the predominant role of secondary organic carbon, OC, and biomass burning at the rural site, as it was less impacted by traffic emission (metals) (Pietrogrande et al. 2019a). Among the extraction solvents, Gamble's solution generated $\mathrm{OP}_{\mathrm{V}}{ }^{\text {DTT }}$ values better correlated with metal concentration, that is consistent with its higher extraction power towards these inorganic components.

Concerning $\mathrm{OP}_{\mathrm{V}}{ }^{\mathrm{AA}}$ responses, significant associations $(p<$ 0.01 ) were found only with EC after PB and GS extraction and none with other investigated parameters (Table 2), independent of the extraction procedure, neither grouping URB nor RUR samples (Tables S4 and S5). Such results are consistent 
with the previously discussed lack of intercorrelation between $\mathrm{OP}_{\mathrm{V}}{ }^{\mathrm{DTT}}$ and $\mathrm{OP}_{\mathrm{V}}{ }^{\mathrm{AA}}$ responses, as they are differently correlated with the same redox-active PM components (Bates et al. 2019; Calas et al. 2018; Fang et al. 2016; Janssen et al. 2015; Pietrogrande et al. 2019a; Simonetti et al. 2018; Visentin et al. 2016)

Based on these results, we can confirm that oxidative properties of the investigated $\mathrm{PM}_{2.5}$ samples depend on both transition metals and organics, with a stronger association of DTT reactivity with chemical components. It should, however, be noted that caution must be exercised when interpreting correlation results, as some conclusions may be potentially affected by other PM components not identified in this study, that may induce ROS production. Further, it is difficult to identify the relative contribution of each component, as it is given by the combination of its individual reactivity associated with its concentration level in PM.

\section{Conclusions}

Overall, the obtained results highlighted that the investigated filter extraction procedures generated differences in the measured oxidative potential of the $\mathrm{PM}_{2.5}$ samples. For our current research goals, of the three tested solvents, the phosphate buffer resulted the solvent of choice, since it provided the most sensible measure of $\mathrm{OP}^{\mathrm{DTT}}$. Although transition metals and quinones have been identified as the chemical components mainly responsible of such results, mechanisms driving the solvent extraction effects on OP responses must be interpreted with caution, as several redox active PM components are involved in ROS production and synergic/antagonistic interactions may be likely operating.

This research used $\mathrm{PM}_{2.5}$ filters from an urban, traffic-dominated, and rural locations collected during spring. To generalize these findings, we plan to explore this topic in the future by looking at $\mathrm{OP}_{\mathrm{V}}{ }^{\mathrm{DTT}}$ and $\mathrm{OP}_{\mathrm{V}}{ }^{\mathrm{AA}}$ responses of $\mathrm{PM}_{2.5}$ with different source contributions and with a more detailed chemical characterization.

This research emphasizes the importance for considering each step of the OP assay procedure in order to select a standardized protocol to enable accurate interlaboratory comparable OP responses to be included in toxicology research on exposures to ambient $\mathrm{PM}_{2.5}$ mixtures.

Supplementary Information The online version contains supplementary material available at https://doi.org/10.1007/s11356-021-12604-7.

Acknowledgements The authors are grateful to the Emilia Romagna Regional Agency Environment Protection and Energy for collecting $\mathrm{PM}_{2.5}$ filters in monitoring campaigns and performing chemical analyses of the collected $\mathrm{PM}_{2.5}$ samples.
Author contribution This collaboration work was carried out among all the authors. MCP designed outlines and wrote the draft of the manuscript. MR performed OP experimental measurements and prepared the figures of the manuscript. DB and AT supervised the $\mathrm{PM}_{2.5}$ filters collection campaigns and reviewed the manuscript. All authors read and approved the final submitted version of the manuscript.

Funding Open Access funding provided by Università degli Studi di Ferrara within the CRUI-CARE Agreement. This work was supported by the Fund for the Scientific Research of the University of Ferrara (FAR 2019).

Data availability The datasets used and analyzed during the current study are available from the corresponding author on reasonable request.

\section{Declarations}

Ethics approval and consent to participate Not applicable.

Consent for publication Not applicable.

Competing interests The authors declare no competing interests.

Open Access This article is licensed under a Creative Commons Attribution 4.0 International License, which permits use, sharing, adaptation, distribution and reproduction in any medium or format, as long as you give appropriate credit to the original author(s) and the source, provide a link to the Creative Commons licence, and indicate if changes were made. The images or other third party material in this article are included in the article's Creative Commons licence, unless indicated otherwise in a credit line to the material. If material is not included in the article's Creative Commons licence and your intended use is not permitted by statutory regulation or exceeds the permitted use, you will need to obtain permission directly from the copyright holder. To view a copy of this licence, visit http://creativecommons.org/licenses/by/4.0/.

\section{References}

Antinolo M, Willis MD, Zhou S, Abbatt JPD (2015) Connecting the oxidation of soot to its redox cycling abilities. Nat Commun 6: 6812. https://doi.org/10.1038/ncomms7812

Abrams JY, Weber RJ, Klein M, Samat SE, Chang HH, Strickland MJ, Verma V, Fang T, Bates JT, Mulholland JA, Russell AG, Tolbert PE (2017) Associations between ambient fine particulate oxidative potential and cardiorespiratory emergency department visits. Environ Health Perspect 125(12):129001. https://doi.org/10.1289/EHP1545

Akhtar US, McWhinney RD, Rastogi N, Abbatt JPD, Evans GJ, Scott JA (2010) Cytotoxic and proinflammatory effects of ambient and source-related particulate matter (PM) in relation to the production of reactive oxygen species (ROS) and cytokine adsorption by particles. Inhal Toxicol 22(Suppl 2):37-47. https://doi.org/10.3109/ 08958378.2010.518377

Bates JT, Weber RJ, Abrams J, Verma V, Fang T, Klein M, Strickland MJ, Sarnat SE, Chang HH, Mulholland JA (2015) Reactive oxygen species generation linked to sources of atmospheric particulate matter and cardiorespiratory effects. Environ Sci Technol 49(22): 13605-13612. https://doi.org/10.1021/acs.est.5b02967

Bates JT, Fang T, Verma V, Zeng L, Weber RJ, Tolbert PE, Abrams JY, Sarnat SE, Klein M, Mulholland JA, Russell AG (2019) Review of acellular assays of ambient particulate matter oxidative potential: methods and relationships with composition, sources, and health 
effects. Review-article. Environ Sci Technol 53(8):4003-4019. https://doi.org/10.1021/acs.est.8b03430

Bein KJ, Wexler AS (2015) Compositional variance in extracted particulate matter using different filter extraction techniques. Atmos Environ 177:24-34. https://doi.org/10.1016/j.atmosenv. 2015.02.026

Calas A, Uzu G, Martins JMF, Voisin D, Spadini L, Lacroix T, Jaffrezo J-L (2017) The importance of simulated lung fluid (SLF) extractions for a more relevant evaluation of the oxidative potential of particulate matter. Sci Rep 7:11617. https:// doi.org/10.1038/s41598-017-11979-3

Calas A, Uzu G, Kelly F, Houdier S, Martins JMF, Thomas F, Molton F, Charron A, Dunster C, Oliete A, Jacob V, Besombes J-L, Chevrier F, Jaffrezo J-L (2018) Comparison between five acellular oxidative potential measurement assays performed with detailed chemistry on PM10 samples from the city of Chamonix (France). Atmos Chem Phys 18:7863-7875. https://doi.org/10.5194/acp-18-7863-2018

Cavalli F, Viana M, Yttri KE, Genberg J, Putaud J-P (2010) Toward a standardised thermal-optical protocol for measuring atmospheric organic and elemental carbon: the EUSAAR protocol. Atmos Meas Tech 3:79-89. https://doi.org/10.5194/amt-3-79-2010

Charrier JG, Anastasio C (2015) Rates of hydroxyl radical production from transition metals and quinones in a surrogate lung fluid. Environ Sci Technol 49(15):9317-9325. https://doi.org/10.1021/ acs.est.5b01606

Collins CD, Craggs M, Garcia-Alcega S, Kademoglou K, Lowe S (2015) Towards a unified approach for the determination of the bioaccessibility of organic pollutants. Environment International 78:24-31. https://doi.org/10.1016/j.envint.2015.02.005

Crobeddu B, Baudrimont I, Deweird J, Sciare J, Badel A, Camproux AC, Bui LC, Baeza-Squiban A (2020) Lung antioxidant depletion: a predictive indicator of cellular stress induced by ambient fine particles. Environ Sci Technol 54(4):2360-2369. https://doi.org/10. 1021/acs.est.9b05990

Fang T, Verma V, Guo H, King LE, Edgerton ES, Weber RJ (2015) A semi-automated system for quantifying the oxidative potential of ambient particles in aqueous extracts using the dithiothreitol (DTT) assay: results from the Southeastern Center for Air Pollution and Epidemiology (SCAPE). Atmos Meas Tech 8(1): 471-482. https://doi.org/10.5194/amt-8-471-2015

Fang T, Verma V, Bates JT, Abrams J, Klein M, Strickland MJ, Sarnat SE, Chang HH, Mulholland JA, Tolbert PE, Russell AG, Weber RJ (2016) Oxidative potential of ambient water-soluble PM2.5 in the southeastern United States: contrasts in sources and health associations between ascorbic acid (AA) and dithiothreitol (DTT) assays. Atmos Chem Phys 16(6):3865-3879. https://doi.org/10.5194/acp16-3865-2016

Fujitani Y, Furuyama A, Tanabe K, Hirano S (2017) Comparison of oxidative abilities of PM2.5 collected at traffic and residential sites in Japan. Contribution of transition metals and primary and secondary aerosols. Aerosol Air Qual Res 17:574-587. https://doi.org/10. 4209/aaqr.2016.07.0291

Gao D, Fang T, Verma V, Zeng LG, Weber RJ (2017) A method for measuring total aerosol oxidative potential $(\mathrm{OP})$ with the dithiothreitol (DTT) assay and comparisons between an urban and roadside site of water-soluble and total OP. Atmos Meas Tech 10(8):28212835. https://doi.org/10.5194/amt-10-2821-2017

Goix S, Uzuc G, Oliva P, Barraza F, Calas A, Castet S, Point D, Masbou J, Duprey J-L, Huayta C, Chincheros J, Gardon J (2016) Metal concentration and bioaccessibility in different particle sizes of dust and aerosols to refine metal exposure assessment. J Hazard Mater 317:552-562. https://doi.org/10.1016/j.jhazmat.2016.05.083

Hedayat F, Stevanovic S, Miljevic B, Bottle S, Ristovski ZD (2014) Review - evaluating the molecular assays for measuring the oxidative potential of particulate matter. Chem Ind Chem Engin Quarterly 21(1-2):201-210. https://doi.org/10.2298/CICEQ140228031H
Janssen NAH, Strak M, Yang A, Hellack B, Kelly FJ, Kuhlbusch TAJ, Harrison RM, Brunekreef B, Cassee FR, Steenhof M, Hoek G (2015) Associations between three specific a-cellular measures of the oxidative potential of particulate matter and markers of acute airway and nasal inflammation in healthy volunteers. Occup Environ Med 72(1):49-56. https://doi.org/ 10.1136/oemed-2014-102303

Jiang H, Ahmed CMS, Canchola A, Chen JY, Lin Y-H (2019) Use of dithiothreitol assay to evaluate the oxidative potential of atmospheric aerosols. Atmosphere 10(10):571. https://doi.org/10.3390/ atmos10100571

Leclercq B, Alleman LY, Perdrix E, Riffault V, Happillon M, Strecker A, Lo-Giudice JM, Garcon G, Coddevillea P (2017) Particulate metal bioaccessibility in physiological fluids and cell culture media: toxicological perspectives. Environmental Research 156:148-157. https://doi.org/10.1016/j.envres.2017.03.029

Longhin E, Holme JA, Gutzkow KB, Arlt VM, Kucab JE, Camatini M, Gualtieri M (2013) Cell cycle alterations induced by urban PM2.5 in bronchial epithelial cells: characterization of the process and possible mechanisms involved. Part Fibre Toxicol 10:63. https://doi.org/ 10.1186/1743-8977-10-63

Luo X, Zhao Z, Xie J, Luo J, Chen Y, Li H, Jin L (2019) Pulmonary bioaccessibility of trace metals in PM2.5 from different megacities simulated by lung fluid extraction and DGT method. Chemosphere 218:915-921. https://doi.org/10.1016/j.chemosphere.2018.11.079

Molina C, Andrade C, Manzano CA, Toro Araya R, Verma V, LeivaGuzmán MA (2020) Dithiothreitol-based oxidative potential for airborne particulate matter: an estimation of the associated uncertainty. Environ Sci Pollut Res 27:29672-29680. https://doi.org/10.1007/ s11356-020-09508-3

Mukhtar A, Mohr V, Limbeck A (2015) The suitability of extraction solutions to assess bioaccessible trace metal fractions in airborne particulate matter: a comparison of common leaching agents. Environ Sci Pollut Res 22(21):16620-16630. https://doi.org/10. 1007/s11356-015-4789-8

Øvrevik J (2019) Oxidative potential versus biological effects: a review on the relevance of cell-free/abiotic assays as predictors of toxicity from airborne particulate matter. Int J Mol Sci 20(19):4772. https:// doi.org/10.3390/ijms20194772

Perrone MR, Bertoli I, Romano S, Russo M, Rispoli G, Pietrogrande MC (2019) PM2.5 and PM10 oxidative potential at a Central Mediterranean site: contrasts between dithiothreitol - and ascorbic acid - measured values in relation with particle size and chemical composition. Atmos Environ 210:143-155. https://doi.org/10.1016/ j.atmosenv.2019.04.047

Pietrogrande MC, Bacco D, Ferrari S, Ricciardelli I, Scotto F, Trentini A, Visentin M (2016) Characteristics and major sources of carbonaceous aerosol in $\mathrm{PM}_{2.5}$ in Emilia-Romagna region (Northern Italy) from four-year observations. Sci Total Environ 553:172-183. https://doi.org/10.1016/j.scitotenv.2016.02.074

Pietrogrande MC, Dalpiaz C, Dell'Anna R, Lazzeri P, Manarini F, Visentin M, Tonidandel G (2018) Chemical composition and oxidative potential of atmospheric coarse particles at an industrial and urban background site in the alpine region of northern Italy. Atmos Environ 191:340-350. https://doi.org/10.1016/j. atmosenv.2018.08.022

Pietrogrande MC, Russo M, Zagatti E (2019a) Review of PM oxidative potential measured with acellular assays in urban and rural sites across Italy. Atmosphere 10(10):626. https://doi.org/10.3390/ atmos 10100626

Pietrogrande MC, Bertoli I, Manarini F, Russo M (2019b) Ascorbate assay as a measure of oxidative potential for ambient particles: evidence for the importance of cell-free surrogate lung fluid composition. Atmos Environ 211:103-112. https://doi.org/10.1016/j. atmosenv.2019.05.012 
Ricciardelli I, Bacco D, Rinaldi M, Bonafè G, Scotto F, Trentini A, Bertacci G, Ugolini P, Zigola C, Rovere F, Maccone C, Pironi C, Poluzzi V (2017) A three-year investigation of daily PM2.5 main chemical components in four sites: the routine measurement program of the Supersito Project (Po Valley, Italy). Atmos Environ 152:418-430. https://doi.org/10.1016/j.atmosenv.2016.12.052

Romano S, Di Salvo M, Rispoli G, Alifano P, Perrone MR, Talà A (2019) Airborne bacteria in the Central Mediterranean: structure and role of meteorology and air mass transport. Sci Total Environ 697:134020. https://doi.org/10.1016/j.scitotenv.2019.134020

Roper C, Chubb LG, Cambal L, Tunno B, Clougherty JE, Mischler SE (2015) Characterization of ambient and extracted $\mathrm{PM}_{2.5}$ collected on filters for toxicology applications. Inhal Toxicol 27(13):673-681. https://doi.org/10.3109/08958378.2015.1092185

Roper C, Chubb LG, Cambal L, Tunno B, Clougherty JE, Fattman C, Mischler SE (2017) Association of IL-6 with $\mathrm{PM}_{2.5}$ components: importance of characterization filter-based $\mathrm{PM}_{2.5}$ following extraction. Water Air Soil Pollut 228:43. https://doi.org/10.1007/s11270016-3219-y

Roper C, Delgado LS, Barrett D, Massey Simonich SL, Tanguay RL (2019) $\mathrm{PM}_{2.5}$ filter extraction methods: implications for chemical and toxicological analyses. Environ Sci Technol 53(1):434-442. https://doi.org/10.1021/acs.est.8b04308

Simonetti G, Conte E, Perrino C, Canepari S (2018) Oxidative potential of size-segregated PM in an urban and an industrial area of Italy. Atmos Environ 187:292-300. https://doi.org/10.1016/j.atmosenv. 2018.05.051

Tuet WY, Chen YL, Xu L, Fok S, Gao D, Weber RJ, Ng NL (2017) Chemical oxidative potential of secondary organic aerosol (SOA) generated from the photooxidation of biogenic and anthropogenic volatile organic compounds. Atmos Chem Phys 17(2):839 - 853 . doi:https://doi.org/10.5194/acp-17-839-2017

Van Winkle LS, Bein K, Anderson D, Pinkerton KE, Tablin F, Wilson D, Wexler AS (2015) Biological dose response to PM2.5: effect of particle extraction method on platelet and lung responses. Toxicol Sci 143(2):349-359. https://doi.org/10.1093/toxsci/kfu230

Velali E, Papachristou E, Pantazaki A, Choli-Papadopoulou T, Planou S, Kouras A, Manoli E, Besis A, Voutsa D, Samara C (2016) Redox activity and in vitro bioactivity of the water-soluble fraction of urban particulate matter in relation to particle size and chemical composition. Environ Pollut 208:774-786. https://doi.org/10.1016/j.envpol. 2015.10.058

Verma V, Fang T, Xu L, Peltier RE, Russell AG, Ng NL, Weber RJ (2015) Organic aerosols associated with the generation of reactive oxygen species (ROS) by water-soluble $\mathrm{PM}_{2.5}$. Environ Sci Technol 49(7):4646-4656. https://doi.org/10.1021/es505577w

Visentin M, Pagnoni A, Sarti E, Pietrogrande MC (2016) Urban $\mathrm{PM}_{2.5}$ oxidative potential: importance of chemical species and comparison of two spectrophotometric cell-free assays. Environ Pollut 219:7279. https://doi.org/10.1016/j.envpol.2016.09.047

Wei J, Yu H, Wang Y, Verma V (2019) Complexation of iron and copper in ambient particulate matter and its effect on the oxidative potential measured in a surrogate lung fluid. Environ Sci Technol 53(3): 1661-1671. https://doi.org/10.1021/acs.est.8b05731

Wiseman CLS (2015) Analytical methods for assessing metal bioaccessibility in airborne particulate matter: a scoping review. Anal Chim Acta 877:9-18. https://doi.org/10.1016/j.aca.2015.01.024

Xing W, Zhao Q, Scheckel KG, Zheng L, Li L (2019) Inhalation bioaccessibility of $\mathrm{Cd}, \mathrm{Cu}, \mathrm{Pb}$ and $\mathrm{Zn}$ and speciation of $\mathrm{Pb}$ in particulate matter fractions from areas with different pollution characteristics in Henan Province, China. Ecotoxicology and Environmental Safety 175:192-200. https://doi.org/10.1016/j.ecoenv.2019.03.062

Yang A, Jedynska A, Hellack B, Kooter I, Hoek G, Brunekreef B, Kuhlbusch TAJ, Cassee FR, Janssen NAH (2014) Measurement of the oxidative potential of $\mathrm{PM}_{2.5}$ and its constituent: The effect of extraction solvent and filter type. Atmos Environ 83:35-42. https:// doi.org/10.1016/j.atmosenv.2013.10.049

Zeng Y, Fan Y, Yan X, Zheng J, Chen SJ, Mai BX (2019) In vitro oral and inhalation bioaccessibility of hydrophobic organic contaminants (HOCs) in airborne particle and influence of relevant parameters. Environmental Research 170:134-140. https://doi.org/10.1016/j. envres.2018.12.025

Publisher's note Springer Nature remains neutral with regard to jurisdictional claims in published maps and institutional affiliations. 